\title{
Challenges of Urban Drainage System in the Emerging Towns of Ethiopia: The Case Study of Assosa Town
}

\author{
Kokeb Zena Besha \\ Lecturer, Department of Civil Engineering, College of Engineering, Assosa University, Ethiopia, East Africa
}

\begin{abstract}
Perhaps one of the most difficult issues a community can face is the question of street flooding and its causes in most emerging towns of Ethiopia. This topic creates extensive debate among local government officials, city administration officials and citizens of Assosa town. The road and drainage infrastructure distribution is not satisfactory for some citizens due to its unfair expansion and distribution activities of the infrastructure. The main focus of the current study was to investigate the urban drainage infrastructure provision, its coverage and managements in Assosa town. In the study physical measurements were made on the drainage channels for data collection. A total of 150 inhabitants of the metropolis were randomly selected and made to respond to some questions in addition to professional and kebele officials. The study found that the special integration between all roads and urban storm water drainage network is found to be $53.6 \%$, the existing condition of drainage system is poor, there is street flooding is common at the study. In addition, the environmental impacts due to poor drainage were adverse at the study area. The study suggests that among others a close coordination with stakeholders and collaboration between private sectors is needed for effective management and suitable operation and maintenance of urban drainage systems.
\end{abstract}

Keywords: Assosa, Environmental Impacts, Infrastructure, Sustainable Drainage, Urban Drainage

\section{Introduction}

Road is an indispensible ingredient of development in any society. In built up areas networks of roads are constructed to support human and vehicular traffic. In complement drainage facilities are provided to ensure timely disposal of sewage and surface water runoff generated from expansive impermeable surfaces. The conveyance of such a drain is facilitated if the ground surface or its invert has sufficient slope (Owuama C. O., Uja E., and Kingsley C. O. 2014).

A good and efficient storm water management is badly required at the moment all over the globe especially in developing countries like Ethiopia. The idea of efficient storm water management is based on the requirement to protect the health of the public, welfare and safety of the public, conservation of water, need to strive for suitable environment, etc. Currently, urbanization has negative impact on urban drainages system in unplanned cities and towns in Ethiopia. The densely populated town and cities are facing water logging and flooding during heavy rainfall. These are common issues mostly in the developing nations (Anisha. N.F and Hossain. S., 2014).The waste water generated from the domestic as well as institutional bodies is merging with storm water into the existing water channel. Lack of planned for separate waste water management such as grey water, storm water, sewerage has to encourage at urban local bodies.

Currently, one of the most difficult issues a community can face is the question of street flooding and its causes. This topic creates extensive debate among local government officials, city administration officials and citizens. Road and drainage infrastructure expansion is not satisfactory for some citizens due to its unfair expansion and distribution activities of the infrastructure.
As stated by Butler and Davis (2000), urban drainage includes two types of fluid, viz, waste water and storm water. Waste water is that after the use life support, process from industry these needs to collected and transported without causing any hazardous issues, but on the other hand storm water is the runoff which caused due to precipitation. Both storm water and waste water needs to be considered for the drainage system planning and design. The main focus of the current study was to investigate the challenges of urban drainage infrastructures and its provision in the emerging towns of Ethiopia, considering Assosa town as a case study. The study discusses the coverage of drainage system, its current status and the environmental impacts due to poor drainage system at the case study area.

\section{Urban Storm Water Drainage System and Management: Basic Concepts}

When rainfalls on to undeveloped land, most of the water will soak into the topsoil and slowly percolate through the soil to the nearest watercourses or groundwater. A small proportion of the rainfall usually 15 to $20 \%$ becomes direct surface runoff that usually drains into watercourses slowly because the ground surface is rough. So for removing water quickly from soil surface adequate drainage system is required. A drainage system can be either natural or artificial. Many areas have some natural drainage which means the excess water flow to the lakes and rivers. Natural drainage, however, is often inadequate and artificial drainage (surface \& subsurface) is required for safely removal of water from road pavements and its surroundings.

Urban storm water management simply stated as everything done within a catchment to remedy existing storm water problems and to prevent the occurrence of new problems. This involves the development and implementation of a combination of structural and non structural measures to 


\section{International Journal of Science and Research (IJSR) \\ ISSN (Online): 2319-7064 \\ Index Copernicus Value (2013): 6.14 | Impact Factor (2015): 6.391}

reconcile the conveyance and storage function of storm water systems, with space and related needs of expanding urban populations. It also involves the development and implementation of a range of measures or best management practices to improve the quality of urban storm water runoff prior to the discharge into receiving waters.

Ethiopian cities and towns at large, are troubled with storm water leading into floods especially during the rainy season due to inadequate installation of drainage infrastructure, poor maintenance of existing drains and the problem is more critical in cities of highland regions like Addis Ababa, Adigrat; though it also exist in cities with flat \& plain geographies like Assosa, Adama, Bahir Dar Woliso and so on. The provision of sustainable drainage system for flat and highland areas is important from different point of views. SUDS are currently the recommended techniques towards solving three major problems in Malaysia which are flash flood, water scarcity and water pollution. Previously, most of the storm water runoff especially in urban areas is catered by conventional drainage systems that carry runoff to the downstream by rapid disposal concept. In order to manage these three major problems, SUDS provide long term solutions to urban drainage management. According to CIRIA (2000), the strategy for sustainable urban drainage systems (SUDS) in regards to storm water is divided into

In the above figure, the storm water management system starts with prevention or good housekeeping measures at the household level and progress through local sources control to larger downstream site and regional control. The concept

\section{Study Objective and Scope}

The main focus of the current study was to investigate the challenges of urban drainage system and its provision in the emerging towns of Ethiopia, Assosa as a case study. The specific objectives are

- To investigate drainage infrastructure coverage at the study area

- To evaluate the conditions of existing drainage system

- To assess the integration between road and urban drainage system and its related problems

- To investigate the environmental impacts due to poor drainage system

\section{The Study Area and Methodology}

\subsection{The Study Area}

The study area is Assosa town. It is located at distance of $662 \mathrm{~km}$ from Addis Ababa to the western direction. It is the capital city of Benishangul Gumuz Regional State, one of the developing regions located at western part of Ethiopia $\left(10^{\circ} \mathrm{N}\right.$ and $\left.34.4^{\circ} \mathrm{E}\right)$. The town has an elevation between $1570 \mathrm{~m}$ to $2000 \mathrm{~m}$ above sea level with relatively flat land topographical features. The projected population of the city is about 45,245. The major economic activities in the town are trading, farming, hotels service and other social services. This town is classified into four Administrative units, namely; (i) Assosa 01, (ii) Assosa 02 (iii) Assosa 03, and three stages to discharge storm water into ground water body as

1) Sources Control: discharging of storm water to the surface where rainfall lands,

2) Site Control: discharging of storm water on the surface water run-off from large areas, such as part of housing estate, major roads, or business parks. The run-off from large urban areas can be channelled to a site control measure using swales (shallow drainage channels), and

3) Regional Control: discharging of storm water with the gathered run-off from a large area at regional level.

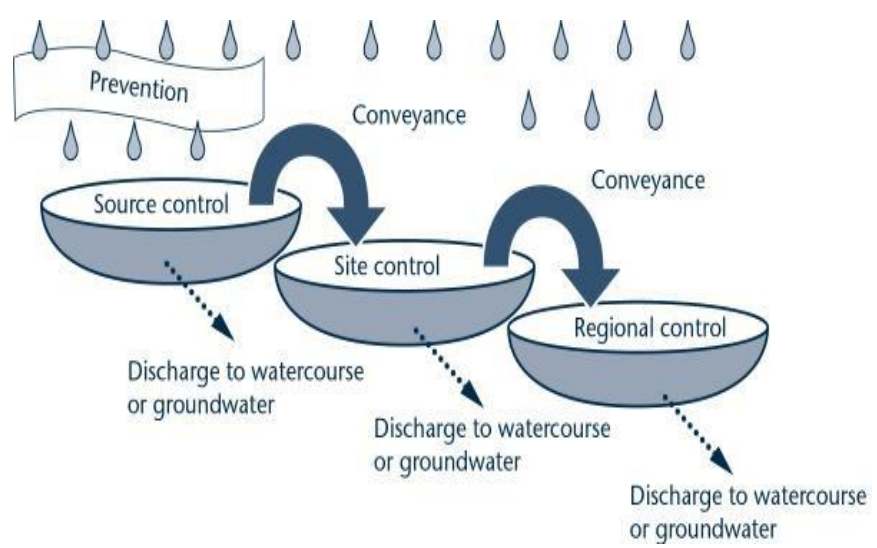

Figure 1: Sustainable Urban Drainage System Management Train (after CIRIA, 2000)

promotes the division of the area to be drain into sub catchment with different drainage characteristics and land use each with own drainage strategy to suite prevailing condition, land use type and hydrogeology type of the site.

(iv) Assosa 04 (Municipality of Assosa Town). Currently, street flooding is common issues in Assosa town due to unplanned and less attention towards the drainage system by city municipality, poor maintenance and management of the existing drains.

\subsection{Research Methodology}

The case study was based on field survey of the actual conditions. In addition to this, primary data were obtained consisted of in-depth interviews with experienced persons from the city municipality responsible for urban drainage infrastructures, kebele officials and the urban communities at the household level. During the study a total of 150 were interviewed and the collected data was recorded. Secondary data were collected in the form of topographical maps, reports, documents, etc.

Table 1: Summary of Respondents Participated for interview

\begin{tabular}{|c|c|c|c|}
\hline S/No & Respondents & Number & Percentage \\
\hline 1 & Municipality Officials & 8 & $5.3 \%$ \\
\hline 2 & Kebele Officials & 6 & $4 \%$ \\
\hline 3 & City Residents & 136 & $90.7 \%$ \\
\hline & Total & $\mathbf{1 5 0}$ & \\
\hline
\end{tabular}

Data related to operation and maintenance of the drainage scheme under study as well as the available non technical problems were compiled and analyze collectively to come up with a comprehensive appreciation of the city's urban drainage system present and potential challenges. Finally, 


\section{International Journal of Science and Research (IJSR) \\ ISSN (Online): 2319-7064 \\ Index Copernicus Value (2013): 6.14 | Impact Factor (2015): 6.391}

the collected data was processed and analyzed using simple mathematical procedures in detail and presented by using graphs, tables, and using photos.

\section{Result and Discussion}

\subsection{Urban Drainage System Coverage}

At the study area, the total length, width and depth of the drains were surveyed and measured. A total of $36.6 \mathrm{kms}$ length of drains was observed. As per the field investigation, the existing drainage system in this city is classified into three types by shape; (i) Rectangular, (ii) Trapezoidal, and (iii) Circular drains. The rectangular drains cover $14.2 \mathrm{~km}$ $(38.6 \%)$, the trapezoidal drain cover $4.3 \mathrm{~km}(11.7 \%)$ and the circular drains cover $18.1 \mathrm{~km}(49.4 \%)$. From the above data, its reveal that high percent of drainage is covered by circular $(49.4 \%)$, followed by rectangular $(38.6 \%)$ and trapezoidal $(11.7 \%)$ drains.

\subsection{Status of Existing Drainage System of the town}

The existing conditions of drainage system at the study area were investigated in detail, and photos are taken to show the existing conditions of each and every drain. Interviews at the household level are also performed to know the perception of the people of the town. The author has designed to find out the existing condition of drains by using the photographic technique and household questioner to ensure performance level such as excellent, very good, good, average, and poor conditions.

Table 2: Respondents response on the status of drainage

\begin{tabular}{|c|c|c|c|c|c|c|}
\hline \multicolumn{7}{|c|}{ syst } \\
\hline & Exce & lent & Very & Good & Poor & Total \\
\hline \multirow{2}{*}{$\begin{array}{c}\text { The existing } \\
\text { conditions of } \\
\text { drainage system of } \\
\text { Assosa is }\end{array}$} & No & -- & 2 & 49 & 99 & 150 \\
\hline & $\%$ & -- & $1.3 \%$ & $32.7 \%$ & $66 \%$ & 100 \\
\hline
\end{tabular}

Source: Own Data Analysis, 2016
Based on field survey data and referring table 2, 99(66\%) of the respondents claimed that the existing condition of the drainage system is poor and unable to perform their intended purpose, and $49(32.7 \%)$ of them said that the drainage infrastructures of the town are at a good condition, whereas $2(1.3 \%)$ of households were responded that the drainage system is at very good condition. In general, the existing drains in the city are not well planed and the people living in the area suffering by different problems like bad smell, breeding of vectors, transmitting of water born disease, and so on.

Table 3: Respondents response on the maintenance of drainage system

\begin{tabular}{|c|c|c|c|}
\hline Raised Question & Yes & No & I don't know \\
\hline $\begin{array}{c}\text { Is there regular } \\
\text { maintenance of drainage } \\
\text { system in Assosa town? }\end{array}$ & 16 & 131 & $3(2 \%)$ \\
$(10.7 \%)$ & $(87.3 \%)$ & \\
\hline
\end{tabular}

Source: Own Data Analysis, 2016

From a total of 150 respondents, $14(10.7 \%)$ of them replied that the urban drainage systems are maintained at their areas, $131(87.3 \%)$ say that the urban drainage infrastructures are not maintained at their areas that is why drains are blocked by solid wastes and resulted in flooding, $3(2 \%)$ of the respondents were neutral. From the above result, most of the existing urban drainage systems of Assosa town are not maintained and managed properly. This revelation should be a source of worry for the government and the people alike. The following pictures taken during the field survey strictly shows the existing conditions of the drainage infrastructures at Assosa town and can be considered as an evidence for the situations.

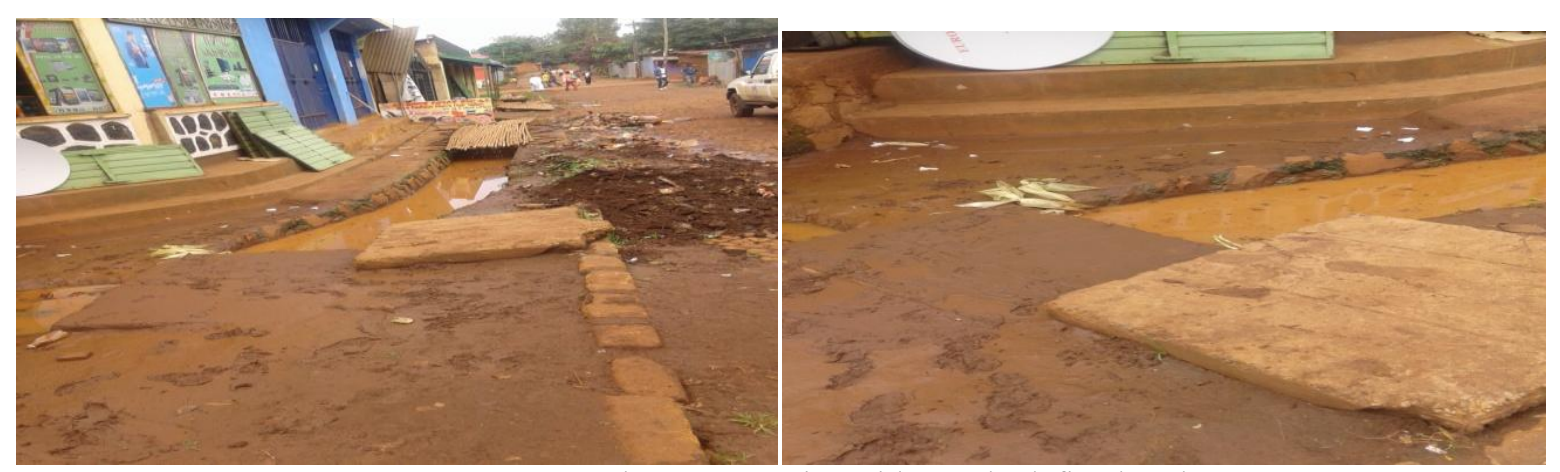

Figure 2: Rectangular Open Drains with poorly defined outlet

As shown in figure 2, a photo was taken by the researcher in May, 2016 during the field work shows that due to poorly defined inlets $\&$ outlets stagnant water is formed in the open drains. 


\section{International Journal of Science and Research (IJSR) \\ ISSN (Online): 2319-7064}

Index Copernicus Value (2013): 6.14 | Impact Factor (2015): 6.391

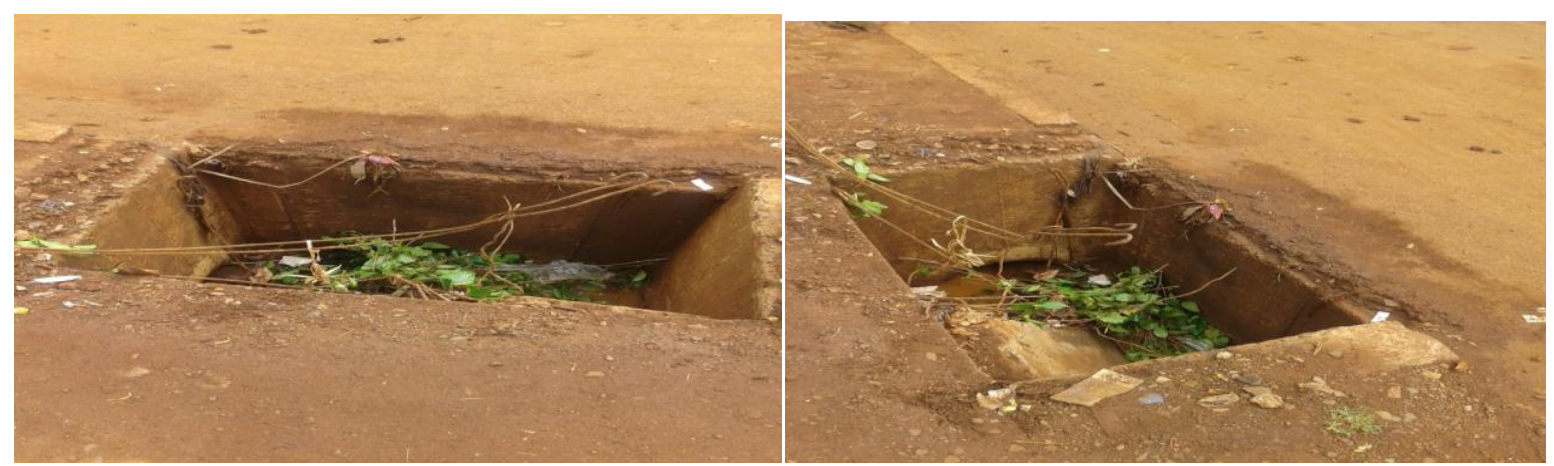

Figure 3: Manholes used as dump place

In figure 3 , one thing the drains are left open, the other thing the waste material extracted from different sources dumped in the manholes and blocked the drainage system as seen.
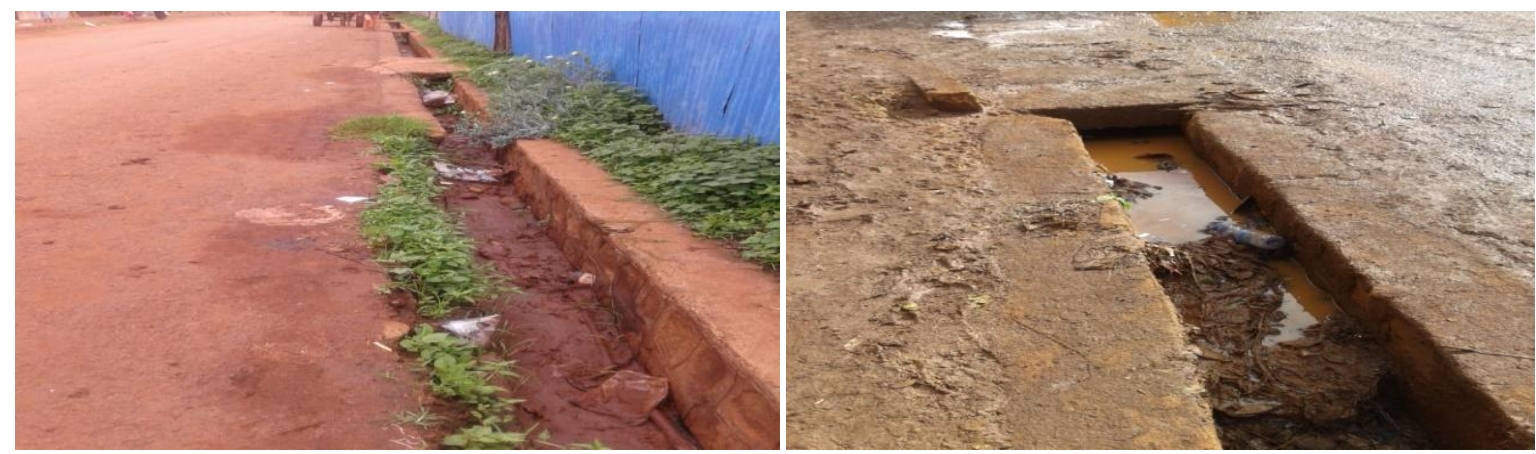

Figure 4: Failed \& blocked Side drains

In figure 4 , the side drains are failed \& blocked by silt sediments due to poor maintenance \& lack of timely supervisions by the concerned bodies.

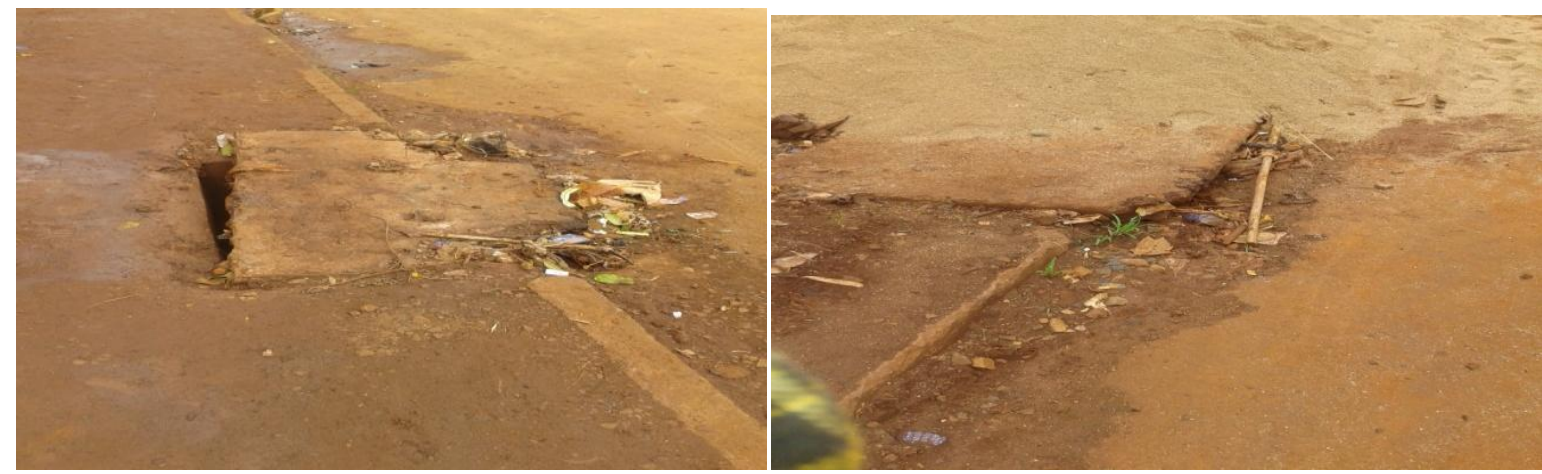

Figure 5: Poorly Executed Manholes

In figure 5, the manhole cover is not properly done and maintained as well due to lack of technical skill \& poor supervision during construction time.

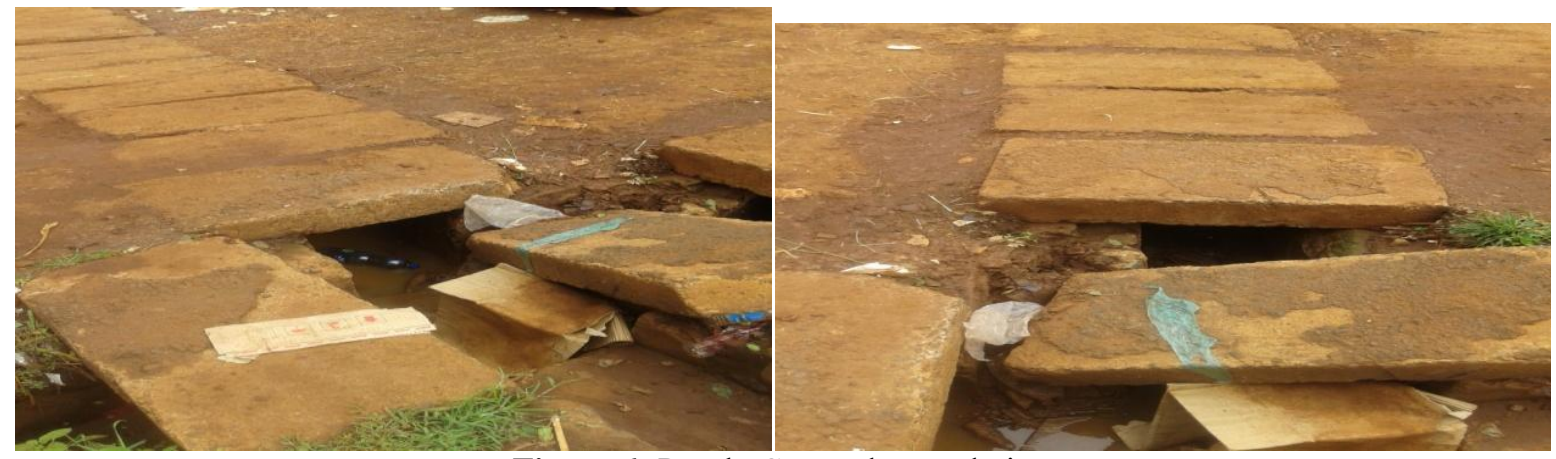

Figure 6: Poorly Covered open drains

Considering figure 6 , the concrete block which is used as a cover for open drains is not properly executed; such types of problems are seen here and there at the study area. In general, it is reflected that drainage condition is poor in

Volume 5 Issue 7, July 2016 www.ijsr.net 


\section{International Journal of Science and Research (IJSR) \\ ISSN (Online): 2319-7064}

Index Copernicus Value (2013): 6.14 | Impact Factor (2015): 6.391

terms of operation and maintenance as well as physical condition as evidenced from figures $2,3,4,5$ and 6 .

\subsection{Integration of Road and Urban Drainage System and its related problems}

According to the field investigation data and its analysis, total roads length in the town is about $68.1 \mathrm{~km}$ by considering all types of roads (primary, secondary and tertiary). Approximately, $53.6 \%$ of the total length is covered by drainage facilities and remaining $48.6 \%$ of the roads are not having drainage facilities. From this analysis the special integration between all roads and urban storm water drainage network is found to be $53.6 \%$. The implication of this is that for a kilometre of road about $536 \mathrm{~m}$ of it has drainage line. Whereas $46.4 \%$ of the existing road does not have a drainage system, which implies that considering a kilometre of road $464 \mathrm{~m}$ of it is without a drainage line. The main point that should be underlined here is that even if $53.6 \%$ of the road network is integrated with drainage line, a significant part of the network is integrated with one side drainage structure.

Table 4: Road and urban drainage infrastructure integration

\begin{tabular}{|c|c|c|c|c|c|c|}
\hline S/No & The Integration of & $\begin{array}{c}\text { Total Length } \\
(\mathrm{km})\end{array}$ & By Rectangular $(\mathrm{km})$ & $\begin{array}{c}\text { By Trapezoidal } \\
(\mathrm{km})\end{array}$ & $\begin{array}{c}\text { By Circular } \\
\text { drains }(\mathrm{km})\end{array}$ & Total Covered $(\mathrm{km})$ \\
\hline 1 & Asphalt Covered & $21.9 \mathrm{~km}$ & $8.04 \mathrm{~km}$ & $4.3 \mathrm{~km}$ & 18.1 & $30.44 \mathrm{~km}$ \\
\hline 2 & Cobble Stone Covered & $3.5 \mathrm{~km}$ & $3.4 \mathrm{~km}$ & -- & -- & $3.4 \mathrm{~km}$ \\
\hline 3 & Local Earth Road & $42.7 \mathrm{~km}$ & $2.7 \mathrm{~km}$ & -- & -- & $2.7 \mathrm{~km}$ \\
\hline & Total & $\mathbf{6 8 . 1}$ & $\mathbf{1 4 . 1 4}$ & $\mathbf{4 . 3 k m}$ & $\mathbf{1 8 . 1}$ & $\mathbf{3 6 . 5 4} \mathrm{km}$ \\
\hline
\end{tabular}

Source: Primary Data, 2016

As per field investigation and from table 4 , from the $21.9 \mathrm{~km}$ of asphalt covered road, $36.7 \%$ of it is integrated by rectangular drains, $19.6 \%$ is integrated by trapezoidal shaped drains, and $41.3 \%$ if integrated by circular drains. Whereas from, $3.5 \mathrm{~km}$ cobble stone paved roads, $97.1 \%$ is integrated with a one sided rectangular shaped drains. In addition, considering $42.7 \mathrm{~km}$ local earth roads, only $6.3 \%$ of it are integrated with rectangular drains. At the study area, the road and drainage system coverage and density are not satisfactory. This implies that flooding keeps continuing, road distress expected to increase, and as a results of these the maintenance and rehabilitation costs for both infrastructures will be increased per year, which is the challenge for the town.

\subsection{Assessing Flooding Condition at the Study Area}

Currently, street flooding and its related effects are common in Assosa town. Most of the drains are unfit for proper functioning. Maintenance activity is done randomly without planning. There are also areas without drainage and access road infrastructures that make life difficult during the rainy season for people living in those areas. To know the perception of the people, interviews were performed with the people living in the four kebeles of Assosa town and the result is shown in table 3 .

Table 5: Respondents Response on how often flooding is happen

\begin{tabular}{|c|c|c|c|c|c|}
\cline { 2 - 6 } \multicolumn{1}{c|}{} & Frequently & Occasionally & $\begin{array}{c}\text { Up to } 5 \\
\text { times }\end{array}$ & $\begin{array}{c}5 \text { to } 10 \\
\text { times }\end{array}$ & $\begin{array}{c}\text { More than } \\
\text { 10 times }\end{array}$ \\
\hline No & -- & 6 & 11 & 104 & 29 \\
\hline$\%$ & -- & $4 \%$ & $7.3 \%$ & $69.3 \%$ & $19.4 \%$ \\
\hline
\end{tabular}

Source: Own Data Analysis, 2016

According to table 5, about 29( $19.4 \%$ ) of households had responded that there is street flooding more than 10 times within a mouth,104 (69.3\%) of households had responded that there is street flooding at the study area 5 up to 10 times within a single month, $11(7.3 \%)$ of the respondents answered that there is street flooding up to 5 times, and 6 (4\%) of the household respondents replied that street flooding is happening occasionally in Assosa town as per the rainy season.

The overall implication of the above discussion indicates that flooding is very common and no proper flow of water channel of the existing drains used to remove from the road pavements at the study area.

\subsection{Environmental Impacts Due to Poor Urban Drainage}

Due to poor maintenance, inadequate drainage infrastructure, and absence of drainage facility in the city, different types of environmental related impacts were caused, such as water born disease, breeding site for vectors like mosquito and water pollutions. The household sampled population reinforces this idea as indicated in table 4 .

Table 6: Respondents Responses about Environmental Problems due to drainage

\begin{tabular}{|c|c|c|c|c|}
\hline \multicolumn{2}{|c|}{ Environmental Impacts } & Yes & No & I don't Know \\
\hline \multirow{2}{*}{ Water Born Diseases } & $N$ & 138 & 12 & - \\
\cline { 2 - 5 } & $\%$ & 92 & 8 & - \\
\hline \multirow{2}{*}{$\begin{array}{c}\text { Breeding site of } \\
\text { Mosquito }\end{array}$} & $N$ & 141 & 8 & 1 \\
\cline { 2 - 5 } & $\%$ & 94 & 5.3 & 0.7 \\
\hline \multirow{2}{*}{ Water Pollution } & $N$ & 119 & 23 & 8 \\
\cline { 2 - 5 } & $\%$ & 79.3 & 15.3 & 5.4 \\
\hline
\end{tabular}

Source: Own Data Analysis, 2016

According to the data of table 6, 138(92\%) of the respondents claimed that due to stagnant water (created by blocked drains) there is a water born diseases as it becomes polluted in different ways, but $12(8 \%)$ of the respondents said that there is no water born diseases in their surroundings as they maintain the drains by themselves. The researcher observed that in poorly drained areas, urban runoff mixes with sewage from overflowing latrines causing pollution and a wide range of problems associated with water born diseases.

In other words, $141(94 \%)$ of the respondents responded that the poor drainage of rainwater and its water logging situation leads to the creation of breeding site for vectors like mosquito, and $8(5.3 \%)$ of them answered that they are 


\section{International Journal of Science and Research (IJSR) \\ ISSN (Online): 2319-7064}

Index Copernicus Value (2013): 6.14 | Impact Factor (2015): 6.391

not come across with such situation in their residential areas. During the field observation time, solid waste blocks the existing drainage system and creates flooding in the street resulting in increase mosquito, bad odour and inconvenience for living in, $1(0.7 \%)$ of the respondents was neutral in this interview. Finally, 119(79.3\%) of the respondents responded that the storm water of the town becomes polluted as it mixes with solid wastes, silt contaminants, domestic waste water and other materials, whereas $23(15.3 \%)$ of them replied that there is no water pollution seen by them due to their negligence, $8(5.4 \%)$ of the respondents had no idea about the problems.

\section{Conclusions and Suggestions}

The provision of urban drainage system is a challenging problem in most cities of the emerging towns of Ethiopia and the situation in Assosa is not different from this. At the study area, the existing drains are not maintained properly, if any it is done randomly. Feasibility study of the drainage system in the town is another challenge by city municipality to action plan. Awareness at the community level for drainage system by municipality is poor since some people are intension of throwing solid waste into existing drains and caused the water logging. In view of the study performed, we recommend that

- At the time of upgrading and maintenance the drainage infrastructures, the City Administration should plan the right time so as to facilitate adequate drainage system.

- A close coordination among stakeholders and collaboration between private sectors is needed for effective management and suitable operation and maintenance of urban drainage systems.

- The City Administration should encourage carrying out the feasibility study in order to identified projects to improve drainage system as soon as possible.

- A paradigm shift to some urban communities is important to reduce the problem of drain blockage at the study area

\section{References}

[1] Anisha. N. F and Hossain. S., (2014): A Case Study on Water Logging Problems in an Urban Area of Bangladesh and Probable Analytical Solutions, 2nd International Conference on Advances in Civil Engineering (ICACE-2014), 26-28 December, 2014 CUET, Chittagong, Bangladesh

[2] Butler and Davis, Urban Drainage Text Book, 2000.

[3] CIRIA, Sustainable Urban Drainage System, 2000.

[4] Municipality of Assosa (2014). Asset Management Plan, Unpublished Document.

[5] Owuama C. O., Uja E., and Kingsley C. O. (2014). Sustainable Drainage System for Road Networking. International Journal of Innovation, Management and Technology, Vol. 5, No. 2.

Volume 5 Issue 7, July 2016 www.ijsr.net 